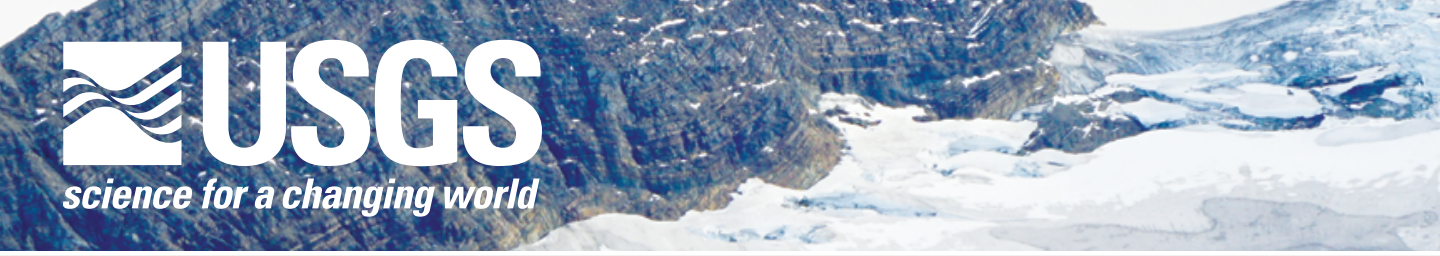

Land Change Science

\title{
Glacier Retreat in Glacier National Park, Montana
}

\section{Introduction}

The volume of land ice on Earth is decreasing. The glaciers in Montana's Glacier National Park (GNP) have decreased in number, area, and volume since the park's establishment in 1910 (Martin-Mikle and Fagre, 2019).

Glacier ice loss has measurable consequences. For example, the loss of glaciers can alter aquatic habitats because glaciers provide cold freshwater to alpine streams during late summer months when streamflow is otherwise low (Clark and others, 2015). Some aquatic species rely on this addition of cold water to survive (Giersch and others, 2016). Another example of the measurable consequence of land ice loss is sea level rise. Globally, small glaciers like those in GNP are numerous enough that their melt can contribute measurably to rising sea levels around the world (Bahr and Radić, 2012).

Scientists, including U.S. Geological Survey (USGS) scientists, study glacier retreat using a variety of methods. Repeat photography provides an objective, qualitative account of historical glacier change. Remote sensing products (fig. 1) and field measurements (fig. 2) yield quantitative data that inform models and other analyses (for example, Brown and others, 2010).

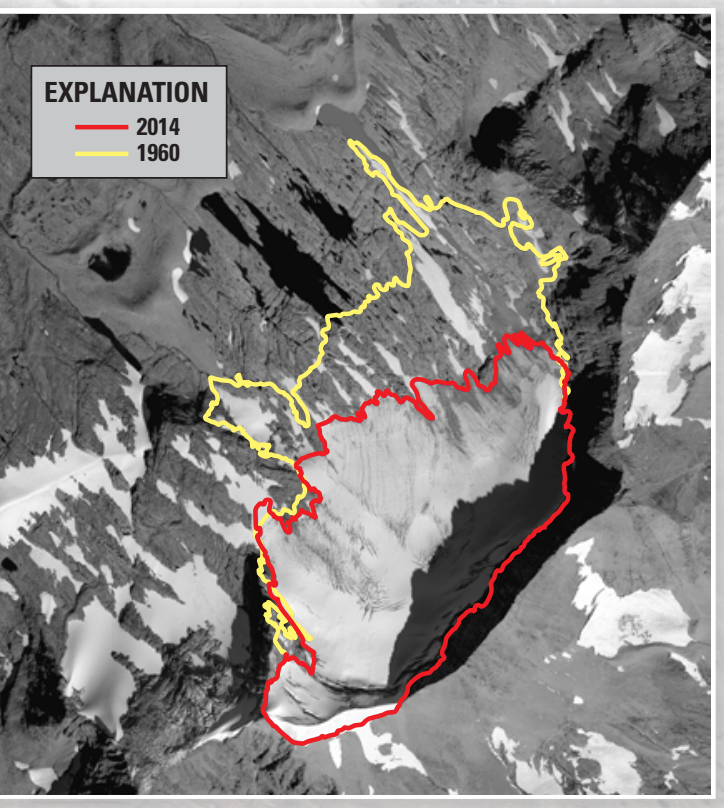

Figure 1. Satellite imagery showing the extent of Sperry Glacier on September 8, 1960 (yellow line) and September 7, 2014 (red line). (Data from McNeil and others, 2019a)

\section{Background}

At the Last Glacial Maximum (approximately 20,000 years ago), GNP was almost entirely encased in ice, with glaciers filling mountain valleys and extending onto the plains (Carrara, 1989). All but the tallest peaks were covered by glaciers. Geologic evidence suggests that by approximately 11,500 years ago, the GNP landscape was nearly ice free (Porter and others, 1983). Lake sediment records suggest that, since approximately 6,500 years ago, small glaciers have been present and active (Munroe and others, 2012).

Comprehensive mapping of glacial moraines (fig. 3) indicates that there were 146 small mountain glaciers in GNP at the Little Ice Age glacial maximum near the mid-19th century (Fagre and Martin-Mikle, 2019).

Since then, every glacier has decreased in area (Fagre and others, 2017). The rate of retreat, however, is not uniform across GNP glaciers, likely because of variations in glacier geometry, elevation, ice thickness, wind effects on snow, snow avalanches (fig. 4), and shading (Florentine and others, 2018).

\section{How Is the U.S. Geological Survey Assessing Glacier Ice Mass?}

GNP contains Sperry Glacier (fig. 5), one of the glaciers closely monitored by the U.S. Geological Survey Benchmark Glacier Project. This project conducts glaciological research that gathers field-based data from select glaciers across North America. These records act as a "finger on the pulse" of glacier change across the United States and are some of the longest direct measurement records on Earth (Baker and others, 2018; O'Neel and others, 2019).

GNP is located near the southern edge of glacierized regions of North America. The decrease of glaciers since the end of the Little Ice Age is due to both natural and humancaused climate change (Marzeion and others, 2014). The multidecadal retreat of GNP glaciers doesn't necessarily mean that every glacier retreats every year. Field measurements collected at stakes installed on the ice (fig. 6) show that Sperry Glacier gains mass during some years (Clark and others, 2017). However, occasional years of mass gain $(2008,2011$, $2012,2016)$ are not enough to offset the multiyear mass loss that has been measured since 2005 (McNeil and others, 2019b).

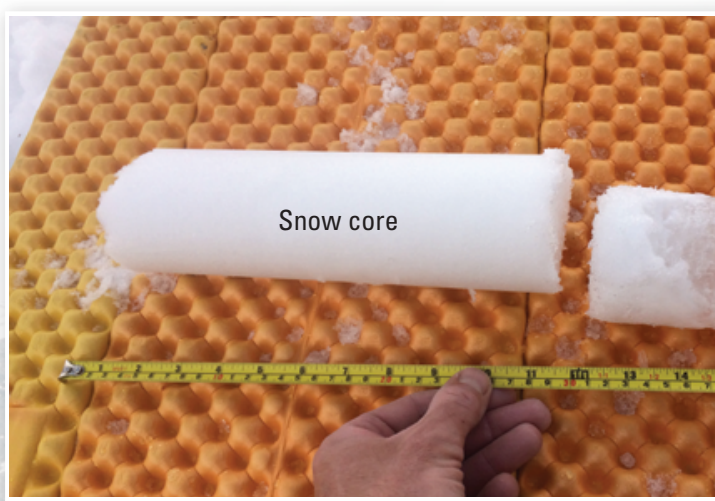

Figure 2. A snow core collected to measure snow density on Sperry Glacier, GNP. (Photograph by Adam Clark, USGS)

\section{Conclusion}

The amount of Earth's land ice that will be lost in the future, and the timing of that loss, depends on the future trajectory of greenhouse gas emissions (for example, Aschwanden and others 2019; Bosson and others, 2019). Because the glaciers in GNP are small, however, their future is more certain and will include continued retreat and mass loss. Ongoing glaciological research will refine our ability to understand and forecast these physical changes and their downstream consequences.

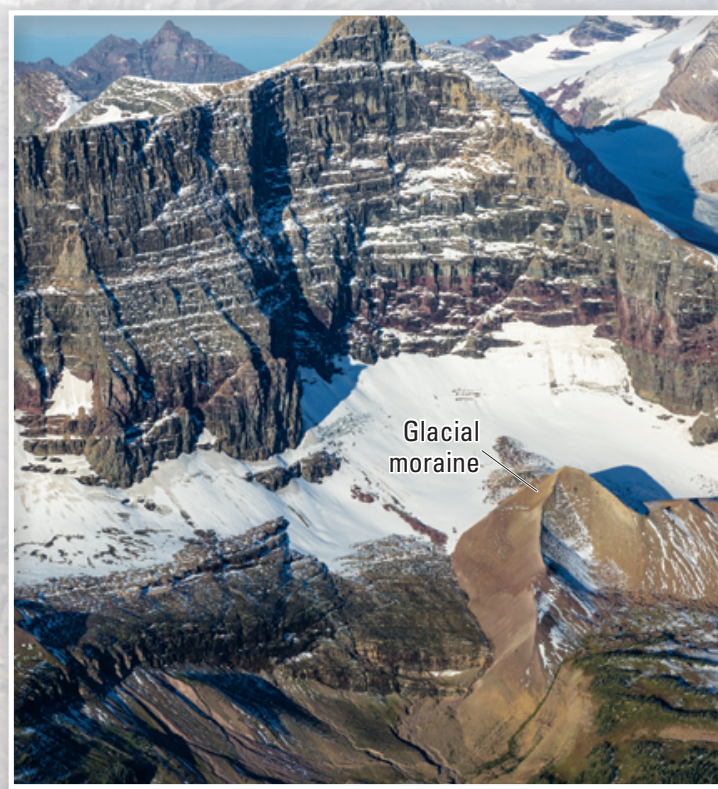

Figure 3. The sharply crested hill in the foreground is a glacial moraine deposited at the Little Ice Age glacial maximum. (Photograph by John Scurlock, USGS) 


\section{References Cited}

Aschwanden, A., Fahnestock, M.A., Truffer, M., Brinkerhoff, D.J., Hock, R., Khroulev, C., Mottram, R., and Abbas Khan, S., 2019, Contribution of the Greenland Ice Sheet to sea level over the next millennium: Science Advances, v. 5, no. 6, 11 p.

Bahr, D.B., and Radić, V., 2012, Significant contribution to total mass from very small glaciers: The Cryosphere, v. 6, no. 4, p. 763-770.

Baker, E.H., McNeil, C.J., Sass, L.C., Peitzsch, E.H., Whorton, E.N., Florentine, C.E., Clark, A.M., Miller, Z.S., Fagre, D.B., and O'Neel, S., 2018, USGS Benchmark Glacier mass balance and project data: U.S. Geological Survey data release, accessed October 2019 at https://doi.org/10.5066/F7BG2N8R.

Bosson, J.-B., Huss, M., and Osipova, E., 2019, Disappearing World Heritage Glaciers as a keystone of nature conservation in a changing climate: Earth's Future, v. 7, no. 4, p. 469-479.

Brown, J., Harper, J., and Humphrey, N., 2010, Cirque glacier sensitivity to 21 st century warming - Sperry Glacier, Rocky Mountains, USA: Global and Planetary Change, v. 74, no. 2, p. 91-98.

Carrara, P.E., 1989, Late Quaternary glacial and vegetative history of the Glacier National Park region, Montana: U.S. Geological Survey Bulletin 1902, 64 p.

Clark, A.M., Fagre, D.B., Peitzsch, E.H., Reardon, B.A., and Harper, J.T., 2017, Glaciological measurements and mass balances from Sperry Glacier, Montana, USA, years 2005-2015: Earth System Science Data, v. 9, no. 1, p. 47-61

Clark, A.M., Harper, J.T., and Fagre, D.B., 2015, Glacier-derived August runoff in northwest Montana: Arctic, Antarctic, and Alpine Research, v. 47, no. 1, p. 1-16.

Fagre, D.B., and Martin-Mikle, C.J., 2019, A comprehensive inventory of maximum glacial extent in Glacier National Park during the peak of the Little Ice Age: U.S. Geological Survey data release, accessed August 2019 at https://doi.org/10.5066/P95YJ3CN.

Fagre, D.B., McKeon, L.A., Dick, K.A., and Fountain, A.G., 2017, Glacier margin time series $(1966,1998,2005,2015)$ of the named glaciers of Glacier National Park, MT, USA: U.S. Geological Survey data release, accessed August 2019 at https://doi.org/10.5066/F7P26WB1.

Florentine, C., Harper, J., Fagre, D., Moore, J., and Peitzsch, E., 2018, Local topography increasingly influences the mass balance of a retreating cirque glacier: The Cryosphere, v. 12 , no. 6 , p. 2109-2122.

Giersch, J.J., Hotaling, S., Kovach, R.P., Jones, L.A., and Muhlfeld, C.C., 2016, Climateinduced glacier and snow loss imperils alpine stream insects: Global Change Biology, v. 23, no. 7, p. 2577-2589.

Figure 6. Photograph of Sperry Glacier in GNP with field measurement sites indicated by red dots. One site (shown by X) has been abandoned as it is no longer located on ice. (Photograph by Adam Clark, USGS)
Martin-Mikle, C.J., and Fagre, D.B., 2019, Glacier recession since the Little Ice AgeImplications for water storage in a Rocky
Mountain landscape: Arctic, Antarctic, and Alpine Research, v. 51, no. 1, p. 280-289.

Marzeion, B., Cogley, J.G., Richter, K., and Parkes, D., 2014, Attribution of global glacier mass loss to anthropogenic and natural causes: Science, v. 345, no. 6199, p. 919-921.

McNeil, C.J., Florentine, C.E., Bright, V.A.L., Fahey, M.J., McCann, E., Larsen, C.F., Thoms, E.E., Shean, D.E., McKeon, L.A., March, R.S., Keller, W., Whorton, E.N., O'Neel, S., and Baker, E.H., 2019a, Geodetic data for USGS benchmark glaciers - Orthophotos, digital elevation models, and glacier boundaries (ver. 1.0, September 2019): U.S. Geological Survey data release, accessed October 28, 2019, at https://doi.org/10.5066/P9R8BP3K.

McNeil, C.J., Sass, L.C., Florentine, C.E., Baker, E.H., Peitzsch, E.H., Whorton, E.N., Miller, Z.S., Fagre, D.B., Clark, A.M., and O'Neel, S., 2019b, Glacier-wide mass balance and compiled data inputs-USGS benchmark glaciers (ver. 3.0, July 2019): U.S. Geological Survey data release, accessed October 28, 2019, at https://doi.org/10.5066/F7HD7SRF.

Munroe, J.S., Crocker, T.A., Giesche, A.M., Rahlson, L.E., Duran, L.T., Bigl, M.F., and Laabs, B.J.C., 2012, A lacustrine-based Neoglacial record for Glacier National Park, Montana, USA: Quaternary Science Reviews, v. 53 , no. C, p. 39-54.

O’Neel, S., McNeil, C., Sass, L.C., Florentine, C., Baker, E.H., Peitzsch, E., McGrath, D., Fountain, A.G., and Fagre, D., 2019, Reanalysis of the US Geological Survey Benchmark Glaciers-Long-term insight into climate forcing of glacier mass balance: Journal of Glaciology, v. 65 , no. 253 , p. 850-866.

Porter, S.C., Pierce, K.L., and Hamilton, T.D., 1983, Late Wisconsin mountain glaciation in the western United States, in Wright, H.E., and Porter, S.C., eds., Late-Quaternary environments of the United States: Minneapolis, Minn., University of Minnesota Press, p. 71-111.

RGI Consortium, 2017, Randolph Glacier Inventory - A dataset of global glacier outlines, version 6.0: Global Land Ice Measurements from Space, accessed August 2019 at https://doi.org/10.7265/N5-RGI-60.

Front page top banner and background photograph by Adam Clark, USGS.

Back page background

photograph by Zach Miller, USGS.

\section{By Caitlyn Florentine}

For more information concerning this publication, contact

USGS Northern Rocky Mountain Science Center

P.O. Box 169

West Glacier, MT 59936

Or visit the Northern Rocky Mountain

Science Center website at

https://www.usgs.gov/centers/norock 